\title{
Invited to a Beheading: A Real Individual in Search of Freedom
}

\author{
Bahare Jalali Farahani \\ Department of Foreign Languages and Literatures, Kharazmi University, Tehran, Iran \\ Email: jalali.bf@gmail.com \\ Javad Momeni (Corresponding author) \\ Department of Foreign Languages and Literatures, University of Tehran, Tehran, Iran \\ E-mail: j.momeni364@yahoo.com
}

Received: 08-08-2016

Published: 10-12-2016
Accepted: 21-10-2016

doi:10.7575/aiac.ijalel.v.5n.7p. 186
Advance Access Published: November 2016

URL: http://dx.doi.org/10.7575/aiac.ijalel.v.5n.7p.186

\begin{abstract}
Among the most prominent political novels of the twentieth century, Invitation to a Beheading is the acme of Nabokov's art in that it was embellished by the finest Nabokovian techniques, and was enriched by thought- provoking ideas. This study is aimed to offer a narratological reading of this novel in search of what its implied author has pictured as the meaning of genuine freedom intended by Nabokov. By analyzing the story and discourse levels of this narrative, we are going to discuss, first, the concepts of 'reality' and 'individuality' in Invitation to a Beheading as the pillars on which the author constructed the ultimate concept of freedom. After discussing the contribution of these two notions, in the last section of this article, dedicated to the questions of ideology and rhetoric, we place the ultimate concept of freedom in the period in which the novel was composed. We discuss how the final picture is in accordance with the peculiarities of the modern world that went through two World Wars and witnessed the outcome of totalitarian systems.
\end{abstract}

Keywords: freedom, individual, reality, narrative, implied author, totalitarian, space, time 1. Introduction

Many Russian Formalists, and, following them, many narratologists attempted to distinguish between the events distinctly organized in the work- sjuzhet- and what is the outline of those events in the work- fabula. Victor Shklovsky, who endeavored to refine and expand the classical boundaries of the two terms, defined fabula as "the events in the novel" and regarded sjuzhet "as an act of formation that meant a defamiliarizing deformation of the fabula". In this definition sjuzhet is considered as a rhythmic form and fabula is termed as nothing but the material for forming sjuzhet (Schmid, Narratology 176-7). Later on, narratologists drew on this formalist discussion, and using their own terminology, called fabula story and termed sjuzhet as discourse; the former being the report of what happened in the text and the latter as what acquaintance readers have with what happens in the work (Schmid, Narratology 186). There was Propp as well, who brought on stage his 31 actants as raw materials of fabula, and classified all parts of narratives based on those 31 stages of the hero's actions. Noteworthy is the fact that modern narrative theorists believe the distinction between the two terms is rather gratuitous, since story is nothing without its unique way of unfolding in the text. Whereas structuralist narratologists commonly focused on chronological differences between fabula and sjuzhet, their poststructuralist generation attacked this notion (Grishakova 118). This argument can be applied to Nabokov's novels in which the ordering of sjuzhet follows the sequence of fabula in most cases because the focus of the works is hugely dedicated to one and only one character, his mind setting and his actions, and not to the ordering of the plot (Boyd 34).

Brian Boyd argues that almost all of this Russian born, American author's works deal with the "hero's obsessive quest after a goal" (34), and therefore, the fabula- sjuzhet order, less strictly than in formalist manner, can be applied to Invitation to a Beheading too. Thus, based on Kafalenos's five stages of fabula, there is a hero, Cincinnatus C., who was in the state of 'equilibrium' before being accused of gnostic turpitude, and is now in the state of 'disruption' after being sentenced to death. He is in 'search of a goal', gaining his freedom, and goes on to 'alleviate' his misery by boosting his power of mind and imagination. At the end he succeeds, leaves the scaffold freely, and starts the state of a 'new equilibrium'. The outcome of this novel, however, violates the expectations of readers because it changes from a tragedy to a fairy-like finale that takes place at the end. The key point in this discussion is how Cincinnatus made it; how he could manage to escape the fate determined for him at the end. These are points that the sjuzhet of the novel reveals to the reader through the distinct literary techniques Nabokov ornamented his work with.

Bryan Boyd discerns three recurring moves in Nabokov's works that he terms as myths; those of return, arrive, and surprise of the ending (36), of which the third one, as discussed above, is easily recognizable in Invitation to a Beheading. The myth of surprising end, meaning the outcome at the end of the story that violates what the reader and the hero expected to happen, can be seen as a "crack in the solid surface of the work's world" (Boyd 36), and that is 
exactly recognizable in what happens at the end of Invitation to a Beheading, when Cincinnatus writes in his diary: "I have discovered it. I have discovered the little crack in life... something genuinely alive, important and vast" (Nabokov 158). After focusing on the different parts of the fabula in this novel, we come to the importance of sjuzhet. As has been discussed, it is in fact the discourse that constructs meaning and conveys the impression to the audience, and for scrutinizing the sjuzhet, we are going to start by analyzing diverse aspects of the novel, as each constructs a part of the concept of freedom the implied author creates for us. In narrative theory, the source of all impressions transmitted to the audience is the work's implied author. For a great deal of narrative theorists, implied author is the construction of each and every reader (Schmid, "Implied Author" 1). Booth, the father of such a controversial concept, believed that readers' sense of the implied author is perceived by not only the receivable meaning, but also by all the emotional and moral implications of characters' actions and experiences. Furthermore, it should be noted that Nabokov, regarded by critics, for long, as a mere parodist, experimenting with irony and genre techniques, is in fact a theoretician who is not only an original creator that resists generalities, but also the author of self- reflexive fiction who has an eye on the conventions of metafiction and fantastic realism (Grishakova 51). As a result, our analysis of the discourse in this novel is inclusive of all the symbols and techniques utilized by the author. Being a theoretician, Nabokov intertwines his own philosophy of life, freedom, and the literary work with his unique way of unfolding his narratives. He cherished freedom, in life, in his literary creation and even in the sentence level so deeply that his free imagination, observable in all aspects of his work, looks for freer horizon, free of all space, time or self-prisons (Boyd 47).

\section{The Crack in the Wall: an Aperture to the 'Real Life'}

Of the conspicuous peculiarities of Invitation to a Beheading is its treatment of 'reality' that stands in prime significance for understanding what freedom means in this work. From the very beginning of the reading process, one recognizes that the author has played with the conventions of Realism; the setting of the story is curiously theatre-like, time passes indifferently to the laws of our time in reality, the boundaries between spaces are violated blatantly, and there exists an 'other world' that is at odds with what is considered as 'our real world'. Grishakova propounds the same proposition and discusses the existence of 'other worlds' in Nabokov's works, and readable signs and hidden meanings configured for observers especially by the help of symbols (94). Thus, the very first thing that should be scrutinized in this novel is the nature of the imprisoning world Cincinnatus lives in, and the picture of 'real world' he dreams of. In regard to the question of reality, then, first the world of Invitation will be analyzed in terms of its nature, its eccentricity, and its importance for defining freedom. In the second part, peculiar time and space of the work and their narratological significance, contributing to the strangeness of the world, and to the construction of the concept of freedom, are analyzed. Finally, the spiritual world of ultimate freedom is discussed.

\section{Theatricality of the Prison of Mind}

The prison in which Cincinnatus is kept is curiously at odds with what one conceives of a jail. For instance, it is written that the guards wear uniform masks that they take off to wipe out their makeups from their faces at nights (Nabokov 17). This is what Connolly calls "the most striking attribute" of Cincinnatus's society that demonstrates theatrical characteristics now and then throughout the story ("Violin" 9). Ample evidence exists in the text for calling the readers' attention to the fact that the work is far too away from a real prison. As another instance, Cincinnatus moves the table in his cell to locate it under the high window in order to climb it up and watch outside of the fortress, while in the very following page readers learn that the table "had been bolted down for ages" (Nabokov 25) and therefore impossible to be moved, no matter how hard the poor man tries to move it. As one goes on reading other examples are found; from the less clear-cut ones like the waltz that Rodrig and Cincinnatus take part in, in the first night of his imprisonment (Nabokov 13), or the 'performed' summer thunderstorm (100), up to the blatant parts like M'sieur Pierre's coming out of a dug whole in the wall of Cincinnatus's cell, wearing special costumes and makeup (122), or Cincinnatus yelling at his mother "play your role...don't let it degenerate into farce. Remember this is a drama. A little comedy is alright,..." (102). It seems that, in its best, the whole society in the narrative is a theatre stage. Meyer brings evidence from the part in which Cincinnatus's family members bring complete furniture, for a brief visit, to the prison, quite like stage decoration (127). What such scenes pose is definitely the artificiality of this lawless society that infringes all that is expected as real and believable. The peculiar percept conveyed here is beyond just the theatricality of the feigned reality in the novel; it hints, delicately, to a system in which there is no law, no rule, and no right for anticipating and expecting consequences; in a word, a totalitarian system that sets the scenes and the events taking place in each act. Cincinnatus complains about this totalitarian control of each and every action, and the transitory nature of rules that are manipulated, strangely interpreted, or broken. He complains "is there in the so-called order of so-called things of which your socalled world consists even one thing that might be considered an assurance that you will keep a promise?" (Nabokov 54).

Another ostentatious element in the text that we interpret as an indicator of the invented reality that the political system designs as make-believe for its subjects in order to control even what they perceive as real is nonnon. This curious object is what Cincinnatus's mother introduces to him as a shapeless, absurd item that is accompanied by a crooked mirror that distorts the ordinary objects placed in front of it. None of the two in itself demonstrated anything comprehensible, yet when the mirror was kept in front of the nonnons, they started to make sense in the way that the very same absurd objects made sensible images in the mirror; flowers, people, and landscapes. Robert Alter in "Invitation to a Beheading: Nabokov and the Art of Politics" writes about two opposite possibilities in interpreting the function of nonnons in the novel. He posits that mirror plays both "good and bad" role in this narrative. Assuming a positive role for it, nonnons are our formless reality that the alchemy of imagination -mirror- can turn it into all beauty 
and order. In this way, nonnon stands for Nabokov's art and imagination that gives meaning to the created world. Nevertheless, Alter also writes of the teasing doubt that remains as readers try to make inference about the whatness of this object that may have a negative connotation in the text (56-57). Going for the second interpretation, we take nonnons as the stage devices and objects that are meaningless in themselves when they are apart from the scenes for which they have been prepared for, and the mirror is that stage or in fact stage directions and scripts that give sense to the whole constructed reality of the system. That is why the features of the prison and its rules are unbelievably and abnormally senseless to the eyes of the readers and even the main character in the novel, yet they are completely normal and in order for other characters who have been dissolved in the artificial world, naturalizing everything that has been written on the stage directions for them. What he comprehends during his 19-day-stay in the prison can sum this section up; Cincinnatus realizes, at the end, that what he cares about most, his wife and his life in the society that never accepted him as its citizen, are not real, but a "crudely" yet "cleverly made" sham (Rutledge 184).

In addition to taking life as a theatre stage, the multiplex ordering of the novel indicates the possibility of considering life as art too. Quite similar to many other aspects of Invitation to a Beheading, here lies another binary opposition of genuine versus mechanical, spiritless art. What the implied author renders is a mere imitation of an authentic life beyond the borders of its copy. In contrast, what Cincinnatus feels inside of him and attempts at rendering in his diary is the envisagement of the real life. For Nabokov, whose literary techniques are always at the service of aggrandizing thematic aspects of his creation, even the words combined to picture the world that imprisons the protagonist stand in contrast to the way Cincinnatus dreams of a better world - "...I allow my thoughts for a free journey from fact to fantasy...much besides, but lack of writing skill, haste, excitement, weakness...I know something...but expression of it comes so hard" (70). In this respect, his imagining Tamara Gardens, as the only natural scene he loved to spend his time in is described in order to emphasize the binary opposition between genuineness and artificiality. As Alter puts it "while Cincinnatus dreams of, and at certain moments his creator pointedly exercises, a beautifully patterned art, the most essential quality of the world that imprisons him is cheap, false, meretricious, mechanical art" (Alter 57).

It is not just the holistic theme of the narrative that conveys this opposition between genuine and fake art, rather this dualism demonstrates itself in terms of photohoroscope of M'sieur Pierre, considering himself as an artist on the one side, and Cincinnatus's interest in writing on the other side. The executioner is fond of 'photohoroscope', a kind of montaging different photos from different people in order to produce a life book for a person. This crazy treatment of people's photos is the culmination of bad art in this society that has already proved its interest in the art of photography (the day Cincinnatus enters his cell, two newspapers with big color pictures of his house are brought to him; also the night before the beheading, Pierre and Cincinnatus are photographed by flashbulb light). As Grishakova puts it, photography signifies the real nature turned into "the dead, fix, immobile, "surrogate' object", and in this novel represents the materialistic, banal art that is supported by the system and is practiced by the representatives of it like M'sieur Pierre (210-211). This so-called artist provides his prey with an example of his art, a chronological album of Emmie's life, from her childhood till death, by means of some photographic tricks that changes her childish face into the face of a young, then mature, and finally a dead woman. Noticeable is Pierre's attempt to define his creation which resembles reality yet is totally fake as a work of art that has imitated natural life in its essence. The outcome is lifeless pictures that were designed to look like real changes in face of a person getting old, yet "conveying something very bizarre to the expert, as a chance steering of a tree's branches may coincide with a sign gesture comprehensible to a deaf-mute" (Nabokov 131).

On the other side of the continuum, there is Cincinnatus who is the master of imagination, and tries to write about what he dreams of, what he imagines to be the real life. In other words, photography in this novel is the imitation of a fake reality, and therefore, is itself artificially constructed by the system. Indeed, writing which deals with imagination and which is able of subverting the fake reality around it functions as the symbol of genuine art - at the end of the novel, Cincinnatus, writing the word 'death' and then crossing it out, indicates his escape from the determined beheading. Detectable in many of his works, the recurrent theme of life as art and text is observable in Nabokov's Ultima Thule, in which the protagonist believes that everything he feels and sees in the world- happiness, life, April- is only a "muddled preface", while the main text is somewhere beyond (Connolly, "Many Faces" 2). Here lies the socio-political facet of the dictatorship as an "aesthetic category, as the tyranny of false art" (Davydov 190) that reveals yet another layer of significance; the political background of all these scenes that conveys the moral aspect of the novel. A totalitarian regime, favoring the mere representation of the fake reality done by photography cannot withstand the perfect art, full of imagination and enriched by individual's perception that pictures a better world.

\section{The Escape from the Prison of Time and Space}

Of prime importance to narratological reading of literary texts is the analysis of time and space in the works. Similar to other aspects of narrative theory, there are classical and postclassical considerations of the two factors, and we are going to utilize both in our reading of Invitation to a Beheading. In classical narratology, time and space have ideological implications in the way that usually they contain sort of dualism in their heart. For instance, the opposition between dark and light, or between open versus closed (Luc Herman and Vervaeck, "Ideology" 220). On the other side, in her narratological reading of Nabokov, Grishakova illustrates that the classical approach takes narratives as representing their events in time and space, and therefore, considers the two as 'containers', while Grishakova, as a modern narratologist employing new perspectives has an eye on the cultural factors, and authors' personal perceptions. Time and space, in this perspective lead to a particular construction of reality in the texts. Absorbed by scientific and aesthetic aspects of these two elements, Nabokov was always concerned with different possibilities for representing time- social 
and subjective; eternity and reversibility- and creating space- objective, subjective, mental and physical (Grishakova 280). In this section, we are going to start with time and then we will move to the question of space in the novel.

In most of Nabokov's novels, narratives are unfolded in a chronological order. This is true about Invitation to a Beheading in which readers start reading from the first day of Cincinnatus's imprisonment and learn about his assumptions, feelings, and experiences till his nineteenth day in the prison that is his execution day. What makes time unique in this work, however, is the impression it generates in readers. From the idiosyncrasies observable in the passage of time, to the sense of captivity time conveys in the novel, the curiosity of time can be comprehended as one confronts the peculiarities of it throughout the reading process. As discussed in previous parts, the body of the individual's experiences in the created world of the narrative is the central object of focus for Nabokov. He believed that art provides the chance of exploring "the individual aberration" of time and space. Thus, it is the observer's subjectivity that determines the temporal ordering, and in this sense, the time in fiction becomes inevitably indeterminate (Grishakova 44, 69). What should be regarded as the ultimate key for interpreting the role time plays in Invitation to a Beheading, hence, is Cincinnatus's perception of time. On the surface, time passes day after day in accordance with the conventions of normal time in reality, yet from the very beginning one feels the artificiality of the passage of time in the depicted society. At his first night in the prison, Cincinnatus, who tries to go to sleep, can hear the clock striking eleven times, thinking for a moment, and striking once more (Nabokov 19), or in another example, he tells his mother about how time is controlled by a watchman who washes off the old hands and dubs new ones-"that's how we live, by tarbrush time, and the ringing is the work of the watchman, which is why he is called a "watch' man" (104). The prisoner gets used to such irregularities in the passage of time, which itself contributes to the construction of the fact that there is no reality in the text but a mere stage whose time, like its other characteristics, is based on what is written in the script. This is one of the peculiarities of Nabokov's fictions that what he pictures as linear chronology is in fact not comparable to standard time and calendar date (Grishakova 76). Soon Cincinnatus realizes that like many other things in the prison, and in the larger scope, the whole society he lives in, even time, is determined based on the desires of the system, signifying not the exact date or hour, but what is considered as appropriate by it. What M'sieur Pierre's photohoroscope of Emmie's supposed life album pictures for us is first the falsehood of all which is considered as realthe fake reality in the novel- and the sovereignty that system imposes on its citizens, determining each and every step of their lives. As an instance, it is written that the prison director announces, falsely, that tomorrow will be the execution day, which is proved wrong, and then he calls calendar "cute, a work of art" (Nabokov 55).

It is crucial to understand why the date of execution is not shared with Cincinnatus. To illustrate the point, we refer to the above mentioned point that time is not standard to Nabokov; it is what each individual constructs, and therefore, can be altered, and even determined based on the person's will. Cincinnatus writes, in his diary, of a world in which "time takes shape according to one's pleasure..." (Nabokov 73). He wishes to escape this prison of time that confines him and his dreams, and it becomes obvious at the end of the novel that the execution day can be any time Cincinnatus feels ready for it, because it is he who can take control of the stage around him as his comprehension of the artificiality of the world he inhabits in becomes more evident to him. It is detected by Grishakova that Nabokov's philosophy is entangled with the assumption of time as prison, and with a dream about a timeless world (126). The notion of metamorphosis is one of the possible interpretations of what takes place at the end of the novel when the real Cincinnatus leaves his crust and escapes the scaffold which is considered as linked to the fact that Nabokov attempts to escape the "spherical prison of time" (Grishakova 96). Like their author, characters like Cincinnatus, lonely in the sham world of the lies seek to find an exit in the fabric of time and space, and it is their creative consciousness that helps them find the crack in the prison of artificial and set dates and hours (Kuzmanovich 23-24).

Space in Invitation to a Beheading can be analyzed from three interrelated aspects; its fake nature, its inclusive sense of confinement, and finally its association with the question of spirituality in this novel. Already mentioned in the above sections, the setting in this text is theatre-like, reminding us of stage configurations from the very beginning of the novel. The most conspicuous example can be made from the ending part, where the word "performance" (Nabokov 156) is used instead of "execution", as if it is a scene in a play. Another instance is when M'sieur Pierre tries to adjust the appropriate lightening of the scaffold scene; "the light is a bit harsh...perhaps you could...there, that's fine. Thank you. Perhaps just a wee bit more...Excellent!" (171). This theatricality contributes to the recognition of readers that the whole setting is unreal and fake, constructed for the purpose of confusing its prisoner and deterring him by its maze-like nature ("Cincinnatus realized that the bends in the corridor had not been leading him away anywhere, but rather formed a great polyhedron" [61]) from realizing its dummy nature. The second main significance of space in this novel is its specific modeling that transfers some sense of confinement to the reader; everywhere is a prison. The eye-catching occasion that first evokes such a feeling in readers is when they are informed that Cincinnatus is the only prisoner in the huge fortress he is kept inside (Nabokov 13). The border of such an enormous prison is ever expanded five pages later, when in a dream-like scene Cincinnatus passes some corridors, after leaving his cell at night, and enters his beloved Tamara Gardens. There, he remembers his feeling of loneliness and opacity against the bound between other citizen and their transparency for each other. Many had already realized his difference before being caught, and he felt as unsafe outside of the prison as inside of it; even outside the fortress was a prison to him. The only shelter Cincinnatus has, inside of which he feels secure, is his free, imaginative mind. All the system attempts at is building a prison for the mind of its citizens so as to make them accept the sham reality as true, the meaningless rules as legal and reasonable, and to force them to yield to its false hegemony. It should be noted that the pervasiveness of this prison of mind that borders between the prison and the city outside is broken in the Tamara garden scene.

At last comes the 'other' space that exists in the novel, the world that Cincinnatus dreams about and develops stronger 
faith in its existence as he realizes the awkward imitation of his society from the real world of freedom, "...surely there must be an original of the clumsy copy" (Nabokov 73). The final scene in the novel can be interpreted in different ways, however, regardless of judging it as metamorphosis, death and rebirth, or simple escape from demise, it is indisputable that Cincinnatus enters the realm of ultimate freedom where "those akin to him lived" (172). It cannot be answered with certainty whether the implied author signals a kind of hereafter or not, but for sure this last scene confirms Cincinnatus's belief in a kind of spiritual world of pure freedom that he considers as a kind of Platonic real realm of idea. Grishakova asserts the same by considering the diegetic world of the novel as "extremely artificial; "space of theatre or circus", while taking the extradiegetic world that Cincinnatus finds himself in as the fourth dimension (239). This spiritual aspect of Invitation to a Beheading is further discussed in the following part.

\section{The Other World of Freedom}

Addressing the issue of spirituality in this narrative, one should notice the two totally distinguished kinds of supernatural elements in the narrative. On the one hand, there are the spider and the acorn that are both proved to be only fake versions of the real creatures, yet masterfully copied like all the other parts of Cincinnatus's prison. On the other hand, there are the spark in the eye of the prisoner's mother talking about her son's mysterious father who was "different" like him, and Cincinnatus's strong vision of another kind of world, real and transcendental, that belongs to a realm beyond the sham, totalitarian society of the novel. The dualism between the two lies in their different sources and indications; the first comes from the totalitarian system, signaling the artificiality of its nature and the salvation it brings about, while the second, subtle as its origin, indicates the real freedom. Since it is through the distinction between these two supernatural elements that one can comprehend the ultimate spiritual notion of the novel, we are going to start our analysis with the first group.

As discussed in the previous parts, everything in the world of Invitation to a Beheading resembles the real version, yet proves to be a mere duplicate, and it is this recognition that allows Cincinnatus to think of the possibility of a real, transcendental world- the source of the copy. The spider which is fed and taken care of by the jailor, and seems to serve as the symbol of entrapment for Cincinnatus is an excellent instance of such dualism. This spider that spins its web day after day is there in order to remind the prisoner of his being caught, and that he is not going to find redemption, since, symbolically, the web becomes tighter and more complete every day. Nevertheless, Cincinnatus, who gains awareness that nothing is what it seems to be, is not impressed by this spider after a while. Contrary to this fake existence is the big, beautiful moth that appears in Cincinnatus's cell toward the end of the narrative. The jailor tries to hunt it for his spider, yet it escapes him and vanishes, implying the possibility of ultimate redemption. Cincinnatus realizes, at the end of the novel, that the spider was just a plastic one, another masterfully imitated particle, as unreal as everything else around him, quite contrary to the moth, an insect as real as life itself. What links the spider to the moth is the fact that they both belong to somewhere beyond the fortress; the former is a supernatural creation of the totalitarian system, inanimate, yet able to feign animation, and fulfill the mission of frustrating Cincinnatus, while the latter is a messenger from the "real" world, so ennobled and spiritualized that reminds Cincinnatus of the artificiality and lifelessness of the surrounding world, and encourages him to keep his faith in ultimate freedom. It is also observed in "Invitation to a Beheading: Nabokov's Violin in a Void" that the spider, resembling Marthe, not only in its movement, but also in its entrapping efforts, stands in opposite to the mesmerizing moth that promises an escape from destruction (Connolly 15-16).

The same can be applied to the acorn that falls on Cincinnatus's bed as he finishes reading a book, Quercus. As he reads this voluminous novel, regarded as the best literary production of his age, about an oak that observes its surrounding for around three hundred years, he gets more and more bored with this unimaginative work. Finishing this "best example" of pseudo-art of the society he lives in, Cincinnatus asks for help, "will no one save me?" (125), and in reply to his question, perhaps, an acorn falls on his bed. Neither Cincinnatus nor the readers can easily interpret this line; is it a sign of help, or is it another sham? The answer, we believe, lies in the next chapter of the novel where Cincinnatus calls imagination as the only savior he has. In this very same chapter, M'sieur Pierre comes out of a whole in the wall of Cincinnatus's cell, playing the role of the savior that Cincinnatus had longed for from the first night he heard someone digging a hole in the wall. Pierre pokes fun at poor Cincinnatus and proves, once more, that there comes no freedom from this artificial world. Also regarded by Barton Johnson as another example for this world/ that world dichotomy (85), considering the acorn as a sign of help proved wrong when, as an answer to his request, Pierre showed up; another fake salvation from a fake friend. Connolly considers the adjective 'dummy' used for acorn, which literally means stage property in Russian as well as sham, as another reason why it should be regarded as belonging to theatrical world of the prison ("Struggle" 170). All this shows that the supernatural acorn, promising fake salvation is of no power in comparison to imagination which is a supernatural help from the other world and brings real salvation for Cincinnatus at the end.

The nature of "the other world" that Cincinnatus terms it, sometimes, the "real" has been a controversial question for critics. Many of Nabokov's heroes attempt to literally leap into another world, overcoming the gravity that pulls them down from reaching other worlds (Wyllie 62). The protagonist of this novel, like Martin Edelweiss and Hugh Person, feels the existence of a transcendental world beyond that motivates him to resist all the suppression. Cincinnatus feels a spark inside and detects the same in his mother's eyes for a moment, and this leads him to believe in "something beyond his horrible life" (Rutledge 127). The centrality of hereafter or beyond in Nabokov's works has been neglected for long by his scholars, yet as his widow testifies, many of his works deal with this mysterious theme. Such metaphysical notion, linked firmly to his ethics and aesthetics, can be best described as a faith in or as an intuition of a timeless and transcendental world above that engenders the sense of immortality. This obviously negates all the claims of diverse 
literary critics who considered Nabokov as a mere "stylist and gamesman" (Alexandrov 569) observable in this novel as well (Alexandrov 566-68). In his contribution to The Garland Companion to Nabokov, Davydov discusses the Gnosticism that exists in the novel, referring to the fact that in this school of spiritual beliefs, which places material world in opposite to the realm of spirituality, our flesh and material world are considered as prison for our soul (192). Cincinnatus is a prisoner, in this respect, in a Godless world (Davydov 198) who gains awareness, during his metaphoric imprisonment in a fortress, about the ecclesiastic realm of divinity, and therefore, reaches salvation.

All in all, as Connolly puts forth, any reductionist reading of this narrative is sort of a misreading that disables us from grasping the rich possibilities of diverse interpretations ("Russian" 142). The vital point that should be also addressed in the discussion of spirituality in Invitation to a Beheading is the hereafter Cincinnatus may have reached after his possible death. No one can state with certainty whether he is beheaded at the end or escapes death, but what matters is that to Nabokov death is merely a physical finish, not the end of the essence of real life (Rutledge 80). Thus, the real world of freedom may be taken as the life after death. We conclude this part by Rutledge who believes that a structural analysis of Nabokov's works ends up in a metaphysical optimism for those who have an intuition of real life (184). The question, now, is who can have such an imaginative perception, and we believe Nabokov has answered this question in this very novel as well, as we are going to explore it in the next part of this article.

\section{The One Alive: An Individualist in Search of Freedom}

Insistent an individualist as Nabokov was (Wyllie 60), freedom to him, in the real sense of the word, meant pure autonomy for each and every person in the society and nothing less. Of prime significance in conceiving the concept of liberty in Invitation to a Beheading is the role an individual plays in achieving this gift. It has been already mentioned in the previous section that the focus of Nabokov's narratives is mainly on a single character and what he experiences and feels, rather than on the plot or specific events. This is due to his cherishing each individual's experiences, concentrating on the isolation of his heroes' consciousness. The conflict between the individual and his society, easily detectable in this novel is a common theme in this author's works (Boyd 32). This focus on individuality in Invitation to a Beheading has reached the extreme point of depicting a society whose only real citizen is Cincinnatus; others are all caricatures whose every aspect of their characterization testifies to their "arbitrariness" and "illegitimacy" (Davydov 189). Surprising as it seems, this is an inseparable element in constructing the whatness of freedom, and a person deserving freedom in this narrative. As an instance, while Rodrig, Roman, Rodion and even M'sieur Pierre wear masks and makeups, and in the court the defense counsel and persecutor wore similar masks, the minute details of Cincinnatus's appearance are described in the very first pages of the narrative. In the story that all characters are described by the appearance of their masks-"doglike or of cloth"- thorough explanation of the gold of Cincinnatus's moustache, or the description of his small scale makes him look real, and places him in obvious contrast to those caricatures surrounding him.

The importance of such detailed description becomes more important when the narrator starts confusing other characters with each other. Readers are perplexed while reading chapter three: Cincinnatus, Rodion, Rodrig and Roman go for a tour on the top of the prison's tower, in the beginning the lawyer's back is "soiled with chalk" (Nabokov, 35), while on the way back it was the director's frock marked with chalk. Furthermore, it is noticeable that during a conversation, Rodrig (the director) and Rodion's (the jailor) speeches are mixed as Rodrig says "Listen to him...he has to know everything. How do you like that Roman Vissarionovich?" the lawyer approves, and then the former says: "yes sir. You ought to be more cooperative, mister", while he gives his keys a rattle." The 'latter' should supposedly refer to Rodrig, yet he just rattles the keys and the lawyer's comment: "that's right Rodion" (33) signals that the speech belongs to the jailor while it had to be articulated by the director. This blatant resemblance in the beginning part of the novel becomes a crystal clear oneness in the end of the narrative. It is when the theatrical setting of the execution scene starts to fall apart, and we read "Roman, who was now many times smaller and who was at the same time Rodrig..." (172). This unique characterization is also addressed by Connolly in his "Nabokov's Violin in a Void", "...the creatures depicted in the novel... are not unique individuals, but stock, interchangeable characters (or caricatures of characters)" (12). Technically, what matters is the reason behind such curious depiction of those peopling the narrative. We believe that what gives Cincinnatus personality, and more exact, reality is the fact that he is a nonconformist who maintains his difference, termed 'opacity' in the novel, in worldview and behavior. It is stated that the reason why he is to be executed is his "impenetrability, opacity" (Nabokov 57). In the society where all people are virtually the same, they are transparent to each other, they all belong to one system of beliefs, and they obey what is determined for them, therefore ,being different- an individualist- is definitely an unforgivable sin- some kind of a gnostic turpitude. "For thirty years I have lived among specters that appear solid to the touch, concealing from them the fact that I am alive and real- (our emphasis) but now that I have been caught, there's no reason to be constrained with you" (Nabokov 55). This individuality that bestows genuine life on Cincinnatus is the reason for both his imprisonment in the artificial scene set by the system for his mind, and his redemption and freedom in real life. Defining 'opacity' as privacy and uniqueness, Invitation to a Beheading is evidently an example of an anti-totalitarian literature (Grishakova 89).

The crucial point not to be underestimated in the question of individuality is that although Cincinnatus was different from others since his childhood, gaining this awareness, and accepting this difference as a merit are what helped him annihilate his prison of mind and become free. As another peculiarity of this novel, Cincinnatus's development from a naïve to a mature individual is rendered for readers in the most idiosyncratic way imaginable. There exist two Cincinnatuses, to whom the narrator referred from time to time, usually in parenthesis. For instance, "Cincinnatus said, "I obey you, specters, werewolves, parodies... However, I demand- yes, demand" (and the other (our emphasis) 
Cincinnatus began to stamp his feet hysterically, losing his slippers)..." (Nabokov 33). Another example is when Cincinnatus says "as you wish...I am powerless anyway." (The other Cincinnatus...a little smaller, was crying, all curled up in a ball.)" (54). What distinguishes the two as the story goes on is that the real Cincinnatus, the one who gains his emancipation at the end, is the braver and the wiser one who derides the rules and strives for finding out the truth. Even in the very examples we have mentioned above, one can detect this difference between the two. These nonidentical Cincinnatuses, however, point to the fact that every individual needs to set their mind free to grasp the artificiality of prisons and to become independent of all what entraps them inside of the vicious circle. The same is discussed from another angle in "Struggle for Autonomy" that suggests the limitation that the system imposes on Cincinnatus lasts as long as he maintains his role as a prisoner, and therefore, the autonomous vision he develops in himself helps him to gain freedom (Connolly 167-8). Thus, when he is finally to be executed, the real Cincinnatus is calm, and as "fear was dragging" the second one "into a system that was perilous to him" (Nabokov 164), he banishes this crust, this weak part of his being and leaves the scaffold. It can be said, in this way, that the protagonist, or at least the real one, was not beheaded and escaped death, entering the realm of real freedom by destroying the scene set for him as a prison. Furthermore, we can accept this interpretation that his flesh was indeed executed; what reached freedom was his soul that, as discussed in the previous section, entered hereafter like a sage.

This flesh versus soul dualism can be found in some parts of the text, “...the subject will now be the precious quality of Cincinnatus; his fleshy incompleteness; the fact that the greater part of him was in quite different place, while only an insignificant portion of it was wandering perplexed...a poor, vague Cincinnatus..." (Nabokov 94). What is precious in an individual, no matter to be taken as the soul or as the mentality, roots inside and has to be discovered by each person in order to generate the power to trespass the limits. This is best pictured for readers in the part that Cincinnatus starts taking off, first, his clothes- his dressing gown and slippers- and then his body organs- his heap and legs and arms- till "what was left of him dissolved into the air and began freely and happily to... "(Nabokov 28), and here readers are left to comprehend what happens to the residue of the protagonist; the answer, of course, is provided at the end of the narrative. "I am taking off layer after layer, until at last...I do not know how to describe it, but I know this: through the process of gradual divestment I reach the final,..., radiant point, and this point says: I am!" (Nabokov 69). The individual, deserving ultimate freedom, is the one who does not obey without choosing, is not a conformist and is therefore a real person who belongs to the real life.

\section{An Individualist Character Overcoming the Unreliable Narrator}

Discussing how Cincinnatus, the only real person in the world of caricatures, annihilates all the barriers that prevent him from reaching freedom is entangled, strictly, with the matter of genre. Although the last part of this article contains a central part dedicated to the discussion of genre, there are two critical points related to the question of individuality that we discuss right in this part. What freedom means in this novel is greatly dependent on the distinctive literary techniques utilized in it. Understanding all the peculiarities of Invitation to a Beheading like its unreliable narrator created by the anti-totalitarian author, and the protagonist's use of language, all aid readers in reconstructing the unique concept of freedom the implied author has pictured.

Reading the first few pages of the novel, readers are presented with scenes violating all the conventions of plausibility. The matter of concern here does not lie in extraordinary events such as the director's dissolving in the room and then entering it once more, or the desk being moved by the protagonist, yet in the next chapter being presented as bolted down to the ground for ages; what matters is the way these scenes are handled by the narrator. Addressing the same issue, Connolly refers to the fact that readers are perplexed when confronting narrator's explanations about Rodrig's face enlivened by "two, and only two bulging eyes" (Nabokov 15). Another instance is Roman's coat being soiled with chalk, and in a page later, reading the same narrated about Rodrig's coat (35-6). This scholar believes that readers cannot regard all these as author's slip-up, though the reason for them is not clear to him ("Violin" 4, 12). We believe these examples invite us to assume unreliability in the narrator of the work. Regarding this, Booth explains that the omniscient narrator- the kind of narrator readers deal with in this novel- is responsible for controlling readers' expectations, leading their hopes and forebodings for characters (173). The same is supposed to happen in the very beginning of the novel when the obtrusive narrator predicts the inevitable death of Cincinnatus at the end of the work"So we are nearing the end..." (Nabokov 12), or further, he describes the pencil given to Cincinnatus, and associates it with the premature end of his life (Connolly, "Struggle" 172), yet it becomes obvious at the end that the protagonist manages to escape death. This false prophecy coupled with all the lack of explanations about the bizarre events in the narrative remind us of another characteristic of the unreliable narrator, that knowing the world created by the author is blocked by this kind of narrator, because usually comments by the author are taken as "trustworthy companion" of readers in the course of passing through the text (Booth 214), and when they are proven wrong or when the narrator neglects those parts in desperate need of explanation, the unreliability of the narrator manifests itself most. In regard with Grishakova's claim, who brings evidence from modern scholars like Francesco Casetti, that focalization and narration, regarded by classical narratologists like Genette as distinguished parties, are inseparable (148), then another witness for the unreliability of our narrator is the violation of what is expected from an external focalizer in this narrative. While it is supposed to resolve the dubious parts of the story (Luc Herman and Vervaeck, "Ideology" 225), the focalizer of Invitation to a Beheading leaves readers baffled by all the left ambiguities. It is noticeable how the bizarre events of the story are narrated with neutral and solemn voice by the narrator, whereas all them are addressed and contemplated upon by Cincinnatus in his diary. In discussing the reason behind choosing an unreliable narrator for this novel, and the role it plays in developing the question of an individual gaining freedom, we start with a noteworthy point by Nünning who reminds us that detecting an unreliable narrator is the result of tracing a dichotomy between what 
the personalized narrator shares with the reader and those the audience perceives from the implied author (100). The emancipatory message of the implied author, picturing a unique vision of freedom for readers is tried to be blurred by the unreliable narrator who is at the service of the author as the representative of a totalitarian system. To shed light on this curious point, we refer to the fact that many of Nabokov's works contain the image of "evil artist- creator" based on early Symbolist notions (Grishakova 94). There are scholars like Karen Jacobs who link an auctorial, omniscient, realist narrator with "institutions of supervision" (Grishakova 159) as it is observable in many parts of the story that the narrator, scientifically and much realistically talks about Cincinnatus as if he is an object of observation for him. Attributing totalitarianism to the author is masterfully conveyed to readers through the protagonist's deriding the author of the Quercus who seems to be seated on the branches of the oak with a camera, observing everything, or as Cincinnatus puts it "spying out and catching his prey" (Nabokov 94). Despite the fact that Nabokov negated the possibility of his characters gaining control of their destiny in the narrative, at the end of Invitation to a Beheading, Cincinnatus, the one real individual destroys all that is determined for him by his author (Pifer 3 ). The unreliable narrator who shows off his authority in the course of the story by his intrusions (when he comments on the short life of the protagonist (Nabokov 12), or when he calls him as "my poor little Cincinnatus" (54), or when suddenly he starts describing his taste about people's hands in parenthesis, completely irrelevant to the scene [78]) is confined, however, when it comes to Cincinnatus's writings that provide readers with all the intact perceptions and viewpoints of him, without the intrusions of the narrator. This happens specifically towards the end of the narrative that the protagonist gains more and more awareness, and as a result, more autonomy. The Narrator's voice is heard as soon as the guards appear and stop Cincinnatus from writing, since they all belong to the same totalitarian system. Connolly states that sometimes it becomes difficult to make distinction between Cincinnatus and the extradiegetic narrator ("Struggle" 181). For instance, as observed in "Reading and Rupture in Nabokov's Invitation to a Beheading", one cannot distinguish between the narrator's telling of Cincinnatus's biography, and Cincinnatus's envisaging and picturing his life in past (Blackwell 41). As we have already discussed in the previous part, the protagonist's free imagination is his true power and it demonstrates itself in overcoming the narrator's voice, first as he imagines his past life, or Tamara Gardens, where the voice of his imagination overshadows that of the narrator as explained above, and then as he writes about his understanding of the theatricality of the set scene around him. The accumulation of his power is demonstrated at the end of the story, when he leaves the scaffold, contrary to the prediction of the unreliable narrator, and moves to the other world.

To Nabokov, the master of language and style, all literary techniques are at the service of meaning construction, and this feature coupled with the importance language has to narratological readings of the texts brings the specific usage of language in this novel into analytical attention. Notable is the passive form of the verbs used for Cincinnatus by the narrator. Instances are ample in the initial part of the text; from the very first sentence of the novel "in accordance to the law the death sentence was announced (our emphasis) to Cincinnatus C." (Nabokov 12), up to his residence in the prison, "he had to be supported" (12), or "the prisoner was brought in" (13) (our emphasis). This excessive use of passive structure for the protagonist is taken by Connolly as the translator's attempt to generate the same impression that the original Russian transitive verbs, making Cincinnatus the object- direct or indirect, produce; he is subordinate to all that is performed on him ("Struggle" 167). This convention, however, is broken in the course of the story as Cincinnatus gains more autonomy; toward the end, for example, there is no use of passive verb for him, and he rejects any help or force in doing things, "by myself, by myself" (Nabokov 171) he repeats. Then he starts asking himself why he should be there, and by realizing how easily, only by his will, he can step out of that sham world, everything starts to collapse in front of his eyes. This gaining control manifests itself not only in his voice overcoming that of the narrator in the diary, but also in the world he tries to create in his writings. Initially, his sentences were incoherent and incomplete, but gradually they started to improve into long, meaningful sentences. Then, he realizes the shortcomings of the language in conveying what he feels inside; he strives to express through words his thoughts (Rutledge 104). Nevertheless, he comprehends the inability of language in helping people express genuine, unconventional ideas, as it is impotent in helping individuals communicating with others. What he writes as his final entry in the diary is just one word crossed out: death. As language proved unfruitful in communication with Marthe or his lawyer or even his mother (the only moment he felt truly in connection with her was in silence, when he found in his mother's eyes the same spark he had in his heart), it could not help him picture the kind of life that was real and transcendental. Connolly has rightly observed that Cincinnatus built a "visionary discourse" to resist the oppression of the "banal formulas" that the representatives of the totalitarian system imposed to him ("Struggle" 174). Like a true artist he always wanted to be, Cincinnatus gave up explaining things via language; he simply envisaged emancipation, and he was free. That is what readers experience in Invitation to a Beheading; no superfluous commentary or explanation, rather excessive language play in order to demonstrate the unreliability of this perplexing medium. In an authentic work of art everything should not be crystal clear to the last degree, but it should be suggestive and multidimensional, and this specific characteristic of Nabokovian art is what Cincinnatus realizes after gaining awareness of the fact that in his sham world, like the script of a simplistic, one-dimensional play, everything has already been written (Connolly, "Struggle" 177). Through writing down his ideas, Cincinnatus develops a firm identity for himself because in this way he boosts what the implied author conveys to the readers as the most essential characteristic of a person deserving freedom; a free mind. It is through his free imagination that the prisoner envisages a better world, comprehends the artificiality of other characters, and transgresses the scenario determined for him by the totalitarian system.

\section{Genuine Freedom as Pictured by the Implied Author}

Every reading brings about an aesthetic judgment, or interpretation on the side of the reader. That interpretation is 
formed by variety of factors, including the very name of the author (and what that name is associated with), the literary techniques utilized in it, and primarily by the clues the implied author of the text has provided readers with. It is approved by many modern narratologists, such as Phelan, that texts are designed in order to affect readers, and the created impression is conveyed to them through words, structure, and intertextuality, and should be critically analyzed by considering how crucial the impression readers receive is ("Rhetoric"209). In narrative theory, the source of all impressions conveyed to the audience is the work's implied author. For many of narrative theorists, implied author is the construction of each and every reader (Schmid, "Implied Author" 1). Booth's concept of implied author in his The Rhetoric of Fiction, evaluates both the audiences' responses and the implied ideology of the texts. Booth asserted that authors invite our critical joining, consciously or unconsciously, by the creation of the implied author; writers' creation in the process of composing, different from the implied authors of their other works. No matter how hard an author tries to be impersonal, readers inevitably build a picture of a writer who is not indifferent toward values $(71,74)$. One can conclude that the message of the implied author is the reader's intuition of the main value in the artistic whole, no matter to what party the true author belongs. This is applicable to modern novels whose authors have done their best not to fill them with moral implications so as to refrain from turning them into "treatise". It should be noted that metaphysics and ethics are inseparable parts of all narratives (Booth 73, 79). In postclassical narratology, ideological interpretation of the texts is considered as a rhetorical factor that should be understood as the communication between the author, as the sender, and the reader, as the receiver (Luc Herman and Vervaeck, "Narrative Fiction"). Thus, it can be inferred that discussing the message of the implied author is to a great extent dependent on each and every reader's comprehension. In our narratological reading of Invitation to a Beheading, we scrutinized diverse parts of the novel so as to here, at the end, complete the puzzle in reference to what we comprehend from the implied author's picture of genuine freedom in our modern times, having an eye on all the thematic and stylistic aspects through which its emancipatory message is transmitted.

Being centered on prison and execution for a vague, arbitrary crime is not the only reason for taking the world of Invitation to a Beheading as an example of a totalitarian system. The fact that all citizens are supposed to think and perceive like each other, and that force and threatening are inextricable part of people's everyday life (shown through the coercive friendship of M'sieur Pierre who imposed himself on Cincinnatus, or by using the fake spider to demoralize him), and that ever-present control of each and every minute part of people's lives (conveyed through the reference to the peephole through which Cincinnatus is observed by the jailor all the time) confirm this interpretation. Striking is the blatant violation of all realistic conventions in this modern work, while the very same message could be conveyed through a realistic story quite well. Narratologically speaking, the text of the novel can be taken as contrastive particles that both maintain and undermine the "social message", as Adorno puts it. This "negative aesthetics", a peculiarity of modern fictions gives life to the matter of "otherness' or the utter subjectivity of the objective world (Grishakova 250), something clearly evident in Invitation to a Beheading. The artificiality that the unrealistic setting of the novel brings about serves to highlight the contrast between the world a totalitarian system creates for its subjects, deprived of any right for free imagination or self-expression, and the other world of" real" life that provides its inhabitants with ultimate joy and emancipation. This world of no time and no definite place seems to be a part of the Soviet Union, specifically due to the Russian names of its characters. There are scholars who put the gnostic nature of Cincinnatus's crime, and his belief in a transcendental world above in opposition to the materialistic system in a communist society, concluding that "the novel's large commitment is to refute the metaphysically materialist and epistemologically realist world view which became the official ideology of the Soviet state" (Dragunoiu 54). However, it should be noted that German language plays a role in this novel as well. For instance, Rodion brings Cincinnatus's fruehstuck which means breakfast in German (Nabokov 96), or it is written that the director's wife has special German accent (129). These tempt us to situate the work more and more into its historical context and take it as a reference to the rise of Nazism and its severe dictatorship. There have been some critical analyses, especially the early ones that detect the same warning about the totalitarian systems of Soviet Union and Germany in this work (Connolly, "Violin" 5). Yet, we believe one should not limit this warning of dictatorship to these two states, since taking languages into consideration, the French name of the executioner, M'sieur Pierre, and some French words used in the narrative suggest, strongly, the concern that can be felt about the pervasive mind control that modern political systems, in wish of spreading duplication, or to put it in Nabokovian terminology, transparency, attempt at. The author admitted that his concerns have been reflected in Invitation to a Beheading, calling the Twentieth century as one of the most turbulent ages that made him direct his contemplations about his forebodings toward the contemporary events in his own peculiar way (Dragunoiu 3). In deciphering this Nabokov's novel, we go back to our discussion of the modern techniques transgressing the realistic standards in the beginning of this section. It is exactly the verisimilitude of realistic novels, invigorating the current system that the individualistic style of this Modernist novel aims at undermining, so as to signal the one possible way out of this totalitarianism: pure individualism that helps people escape from the prison of mind that the modern dictatorship imposes on them. Such emancipatory belief being reflected in this narrative is totally expectable from an extreme individualist like Nabokov who also believed in traditional Liberalism his father was committed to and died for (Nicol 625, 627).

As for the envoi, we end our discussion by addressing the strange smallness of the protagonist. Cincinnatus is peculiarly small and fragile, naturally incapable of heroic showdowns expected from cliché rebels. What this unfitness for fighting reveals is that it is not physical combats but the power of the mind that can overcome the prison imposed on the minds of people in modern times. Rebels like Cincinnatus, are symbolically small in front of the system and its extensive authority, yet gaining awareness as the first step in fighting the arbitrary rules help them to grow. “...the greater part of 
him was in a quite different place, while only an insignificant portion of it was wandering, perplexed, here...a comparatively stupid Cincinnatus...foolish as people are in their sleep" (Nabokov 93); the ignorance imposed on people being referred to as 'sleep'. The simple, everyday person Cincinnatus is, ultimate freedom becomes him, an individualist, who stood above others because of his free mind, capable of imagining a better world. His changing the determined scene of his execution and gaining freedom make him, metaphorically, greater than all the caricatures that were all the same,

Cincinnatus slowly descended from the platform and walked off through the shifting debris. He was overtaken by Roman, who was now many times smaller and who was at the same time Rodrig: "what are you doing!" he croaked..."everything was ready, everything was finished"...little was left of the square. The platform has long since collapsed...Cincinnatus made his way in that direction where, to judge by the voices, stood beings akin to him (172).

\section{Conclusion}

In this article, the researchers have attempted to offer a narratological reading of Invitation to a Beheading in search of what its implied author has pictured as the meaning of genuine freedom. By analyzing the story and discourse levels of this narrative, we have discussed, first, the concepts of 'reality' and 'individuality' presented in the novel as the pillars on which the author constructed the ultimate concept of freedom. In regard with reality, Nabokov puts the hereafter in contrast to the materialist life we live, giving privilege to the former which he considers as 'the real'. This notion is merely understood by the ones who have developed a strong sense of individuality in themselves. As with Cincinnatus, through writing down his ideas, he cements a firm individuality for himself because in this way he strengthens what the implied author conveys to the readers as the most essential characteristic of a person deserving freedom; a free mind. It is through his free imagination that the prisoner envisions a better world, comprehends the artificiality of other characters, and transgresses the scenario determined for him by the totalitarian system. After discussing the contribution of these two notions, in the last part of this article, we've placed the ultimate concept of freedom in the period the novel was written by focusing on the questions of ideology and rhetoric. What we have inferred from the implied author is that genuine freedom is the freedom of mind and only those who have been endowed with a great sense of individuality can achieve it. This freedom leads us to plumb the depth of the sham of the totalitarianisms.

\section{References}

Alexandrov, Vladimir E. "The Otherworld." The Garland Companion to Vladimir Nabokov. Ed. Vladimir E. Alexandrov. New York: Rutledge, 1995. 566-70. Web.

Alter, Robert. "Nabokov's Invitation: Nabokov and the Art of Politics." Nabokov's Invitation to a Beheading a Critical Companion. Ed. Julian W. Connolly. Evanston: Northwestern UP, 1997. 47-66. Print.

Blackwell, Stephen. "Reading and Rupture in Nabokov's Invitation to a Beheading." The Slavic and East European Journal 39.1 (1995): 38-53. Web. 30 Aug. 2015.

Booth, Wayne C. The Rhetoric of Fiction. 2nd ed. Chicago: U of Chicago, 1963. Web.

---. "Resurrection of the Implied Author: Why Bother?" A Companion to Narrative Theory. Ed. James Phelan and Peter J. Rabinowitz. Malden: Blackwell, 2005. 75-88. Web.

Boyd, Brian. "Nabokov as Storyteller." The Cambridge Companion to Nabokov. Ed. Julian W. Connolly. New York: Cambridge UP, 2005. 31-48. Web.

Connolly, Julian. "Introduction: The Many Faces of Vladimir Nabokov.". The Cambridge Companion to Nabokov. Ed. Julian W. Connolly. New York: Cambridge UP, 2005. 1-10. Web.

---. "Invitation to a Beheading: Nabokov's Violin in a Void." Nabokov's Invitation to a Beheading a Critical Companion. Ed. Julian W. Connolly. Evanston: Northwestern UP, 1997. 3-46. Print.

---. "The Major Russian Novels." The Cambridge Companion to Nabokov. Ed. Julian Connolly. New York: Cambridge UP, 2005. 135-150. Web.

---. "The Struggle for Autonomy.” Nabokov's Early Fiction. Ed. Julian W. Connolly. Cambridge: Cambridge UP, 1992. 161-84. Web.

Davydov, Sergej. "Invitation to a Beheading." The Garland Companion to Vladimir Nabokov. Ed. Vladimir E. Alexandrov. New York: Rutledge, 1995. 188-202. Web.

Dragunoiu, Dana. "Vladimir Nabokov's Invitation to a Beheading and the Russian Radical Tradition." Journal of Modern Literature 25.1 (2001): 53-69. Web. 30 Aug. 2015.

Grishakova, Marina. The Models of Space, Time and Vision in V. Nabokov's Fiction: Narrative Strategies and Cultural Frames. Tartu: Tartu UP, 2006. Web.

Herman, Luc, and Bart Vervaeck. "Ideology." The Cambridge Companion to Narrative. Ed. David Herman. New York: Cambridge UP, 2007. 217-30. Print.

--,--. "Ideology and Narrative Fiction." Handbook of Narratology (2013): n. pag. Web. 
Johnson, D. Barton. "Spatial Modeling and Deixis: Nabokov's Invitation to a Beheading." Poetics Today 3.1 (1982): 81 98. Web. 30 Aug. 2015.

Kuzmanovich, Zoran. "Strong Opinions and Nerve Points: Nabokov's Art and Life." The Cambridge Companion to Nabokov. Ed. Julian W. Connolly. New York: Cambridge UP, 2005. 11-30. Web.

Meyer, Priscilla. "Nabokov's Short Fiction." The Cambridge Companion to Nabokov. Ed. Julian W. Connolly. New York: Cambridge UP, 2005. 119-34. Web.

Nabokov, Vladimir Vladimirovich. Invitation to a Beheading. Trans. Dmitri Nabokov. New York: Vintage, 1989. Ebook.

Nicol, Charles. "Politics." The Garland Companion to Vladimir Nabokov. Ed. Vladimir E. Alexandrov. New York: Rutledge, 1995. 625-28. Web.

Nünning, Ansgar F. "Reconceptualizing Unreliable Narration: Synthesizing Cognitive and Rhetorical Approaches." A Companion to Narrative Theory. Ed. James Phelan and Peter J. Rabinowitz. Malden: Blackwell, 2005. 89-107. Web.

Pifer, Ellen I. "Nabokov's "Invitation to a Beheading": The Parody of a Tradition." Pacific Coast Philology 5 (1970): 4653. Web. 30 Aug. 2015.

Rutledge, David S. Nabokov's Permanent Mystery: The Expression of Metaphysics in His Work. Jefferson, NC: McFarland, 2011. Web.

Schmid, Wolf. "Implied Author." The Living Handbook of Narratology. N.p., 16 May 2014. Web. 20 Aug. 2015.

---. Narratology: An Introduction. New York: Walter De Gruyter, 2010. Web.

Wyllie, Barbara. Vladimir Nabokov. London: Reaktion, 2010. Web. 